\title{
Current Therapies and New Targets to Fight Melanoma: A Promising Role for the B3-Adrenoreceptor
}

\author{
Luca Filippi ${ }^{1, *(\mathbb{D})}$, Gennaro Bruno ${ }^{2,3, *(\mathbb{D})}$, Vladana Domazetovic ${ }^{2,3} \mathbb{C}$, Claudio Favre $^{3}$ and \\ Maura Calvani ${ }^{3}$ (D) \\ 1 Neonatal Intensive Care Unit, Medical Surgical Feto-Neonatal Department, A. Meyer University Children's \\ Hospital, 50139 Florence, Italy \\ 2 Department of Health Science, University of Florence, 50139 Florence, Italy; vladana.domazetovic@unifi.it \\ 3 Department of Paediatric Haematology-Oncology, A. Meyer University Children's Hospital, \\ 50139 Florence, Italy; claudio.favre@meyer.it (C.F.); maura.calvani@meyer.it (M.C.) \\ * Correspondence: 1.filippi@meyer.it (L.F.); gennaro.bruno@unifi.it (G.B.)
}

Received: 26 March 2020; Accepted: 25 May 2020; Published: 30 May 2020

\begin{abstract}
Melanoma is one of the most aggressive types of cancer and the most deadly skin cancer. According to World Health Organization, about 132,000 melanoma skin cancers occur globally each year. Thanks to the efficacy of new therapies, life expectation has been improved over the last years. However, some malignant melanomas still remain unresponsive to these therapies. The $\beta$-adrenergic system, among its many physiological roles, has been recognized as the main mediator of stress-related tumorigenic events. In particular, catecholamine activation of $\beta$-adrenergic receptors ( $\beta$-ARs) affects several processes that sustain cancer progression. Among the $\beta$-AR subtypes, the $\beta 3$-AR is emerging as an important regulator of tumorigenesis. In this review, we summarize data of different experimental studies focused on $\beta 3$-AR involvement in tumor development in various types of cancer and, particularly, in melanoma. Taken together, the preclinical evidences reported in this review demonstrate the crucial role of $\beta 3$-AR in regulating the complex signaling network driving melanoma progression. Therefore, a need exists to further disseminate this new concept and to investigate more deeply the role of $\beta 3$-AR as a possible therapeutic target for counteracting melanoma progression at clinical level.
\end{abstract}

Keywords: melanoma; $\beta 3$-adrenergic receptor; cancer therapies

\section{Introduction}

Melanoma is still one of the most aggressive and chemotherapy-resistant human cancers, originating from melanocytes. Melanoma development, as for the majority of skin cancers, is related, at least in part, to ultraviolet radiation exposure and to years of any protracted sun/UV exposure. This relationship explains why melanoma location is related to sun exposure [1]. Further risk factors for melanoma development include a particularly fair skin, hair, and eye color phenotypes associated with increased sun sensitivity, the presence of dysplastic nevi, and genetic predisposition [2].

The incidence of invasive melanoma has been rising worldwide over the past two decades, despite numerous efforts to enhance primary prevention and early detection [3]. The overall incidence has been increasing particularly in the United States, with an increase by $270 \%$ over the past 30 years [4]. Melanoma predominantly affects the Caucasian population, whose risk is 10-fold increased compared to people with dark skin pigmentation [4], and represents the fifth most frequent cancer in men and the sixth most common cancer in women in the United States [5]. The region with the highest incidence of 
melanoma is Australia with the age-standardized incidence rate increased by 181\% between 1982 and 2016, from 27 cases per 100,000 in 1982 to an estimated 50 cases per 100,000 in 2016 [6].

It has been assessed so far that adrenergic system, via catecholamine release following stress events, is able to sustain cancer progression and influence the outcome of patients affected by several malignancies. In this contest, $\beta$-adrenergic receptors ( $\beta$-ARs) have been identified as the main responsible actors of stress-enhanced tumor-related pathways [7]. $\beta$-ARs are G protein-coupled receptors responsible for mediating many physiological and pathological responses in humans and animals. Although initially two $\beta$-AR subtypes have been identified, $\beta 1-A R$ and $\beta 2-A R$ [8], the existence of the third $\beta$-AR subtype, firstly described as "atypical $\beta$-adrenoreceptor" [9], and named $\beta 3-A R$, has been acknowledged much later. We know that all three $\beta$-ARs can be activated by noradrenaline and adrenaline, although with different affinity. The two catecholamines are, indeed, equipotent at the $\beta 1-\mathrm{AR}$, while adrenalin is 100-fold more selective for $\beta 2-\mathrm{AR}$. On the contrary, noradrenaline is more potent than adrenaline as a $\beta 3$-AR agonist [10]. All three $\beta$-ARs are expressed in numerous cell types of the tumor microenvironment; therefore, dissecting the effects related to each specific $\beta$-AR subtype involved in tumor progression is a complex but required objective.

Since in melanoma, especially in resistant subtypes, new therapies are needed; in light of a continuous search for alternative therapeutic strategies, $\beta$-AR modulators cannot be forgotten. In particular, recent preclinical studies evidence the emerging role of $\beta 3$-AR in melanoma.

\section{Current Therapies in Melanoma}

For cutaneous melanomas localized and not outspread beyond the site of origin, surgical excision remains the primary modality of treatment, with a high five-year relative survival rate but yet dependent on the tumor mass thickness and ulceration. However, survival percentage drops dramatically for patients diagnosed with advanced or metastatic melanoma (65\% for regional to $25 \%$ for distant melanoma lesions), because treatment options are limited [11]. Chemotherapy, such as Dacarbazine (DTIC) [12] or Temozolomide [13], has been shown to offer only modest benefits and severe adverse effects, and has not been able to significantly change the prognosis. However, in the past decade, the approval of many new treatments for metastatic disease has contributed significantly to the recent increase in survival rate, as recently reported by the American Cancer Society [14].

In 2011, the US Food and Drug Administration (FDA) approved Ipilimumab for metastatic disease therapy, the first immune checkpoint inhibitor (an anti-CTLA-4 drug), for the treatment of advanced melanoma, and Vemurafenib, a BRAF inhibitor, for the treatment of unresectable or metastatic melanoma with BRAF V600E mutation. Then, two new monoclonal antibodies, Nivolumab and Pembrolizumab targeting the anti-programmed cell death protein 1 (PD-1) were approved and marketed in 2014 [15]. At the same time, another drug able to inhibit BRAF, Dabrafenib, was approved by the FDA in 2013 [16], but also MEK inhibitors, drugs able to inhibit the mitogen-activated protein kinase enzymes MEK1 and/or MEK2, such as Trametinib or Cobimetinib, were made available and approved, respectively, in 2013 and 2015. All these new drugs have been used alone or in combination [17]. These new pharmaceutical opportunities, and the ability to combine these drugs to target different immune checkpoints, have contributed to the sharp drop in mortality [18]. The overall survival rate at 5 years was $52 \%$ in patients treated with Nivolumab and Ipiliumubab versus $44 \%$ in patients treated only with Nivolumab and $26 \%$ in those treated only with Ipilimumab [19]. Alongside the higher cost of biological therapies compared to traditional ones for the treatment of melanoma, the significant increase in survival has been associated with an impressive increase of expenses, raising the question of financial sustainability, mainly for public health systems [20]. For this reason, the availability of new options, hopefully less expensive, represents a matter of priority.

Despite the significant improvements in life expectations for patients with historically poor outcomes attributable to new immunotherapies, a significant number of patients still remain far from significant long-lasting benefits. Therefore, alternative therapies are definitely required. 


\section{Role of Stress and $\beta$-ARs in Cancer}

The longstanding hypothesis of the existence of a relationship between stress (for example related to surgery, but also linked to psychosocial factors, such as depression) and tumor onset, has been confirmed in the last years through numerous experimental and clinical investigations [21,22]. The explanation of this relationship must be sought in the activation of the sympathetic nervous system and the release of stress-related mediators such as catecholamines, whose concentrations increase in the tumor microenvironment [23]. In particular, sympathetic nervous system and catecholamine exert pro-tumorigenic actions through the modulation of $\beta$-ARs, which in turn affect several biological processes related to cancer progression or metastasis, such as tumor cell proliferation, invasiveness, migration and vascularization $[7,22,24,25]$. Psychological aspects affecting melanoma patients, such as fear of cancer recurrence, anxiety, depression and risk of suicide, have been documented by several studies [26-28]. Therefore, in light of the existing link between stress and cancer progression in melanoma patients, interventions aimed to provide efficient psychological support are of uttermost importance in management of melanoma patients [29].

In preclinical murine models, $\beta$-ARs antagonists have shown the ability to block stress-induced enhancement of tumor progression in several malignancies, including melanoma [30,31], breast [32], prostate [33], and leukemia [34] cancers. On the contrary, $\beta$-ARs agonists have been found to enhance in vivo tumor progression and metastasis $[32,33,35]$, confirming the critical involvement of $\beta$-ARs in cancer biology. Among the direct effects exerted on tumor cells, some reports demonstrated that $\beta$-ARs are also able to regulate pathways in non-tumoral cells of tumor microenvironment [36]. Despite the first data highlighted a prominent role of the $\beta 2$-AR subtype in regulating tumor-relating pathways [37], recent studies have directed attention to $\beta 3$-AR subtype as an important player in cancer biology.

\section{4. $\beta$-ARs in Melanoma}

The involvement of stress in melanoma development and progression is definitely clear and well established by biological and clinical evidences [38]. A large amount of in vitro and in vivo experimental data together with epidemiological studies have shown that $\beta 2$-AR is the $\beta$-AR subtype mostly involved in mediating the effects of catecholamines in cancer [39].

In melanoma, the role of $\beta$-adrenergic system has been evaluated by in vitro and in vivo studies before testing $\beta$-adrenergic blockers in humans. In vitro studies confirmed the presence of $\beta$-ARs in animal and human melanoma cells. These studies also confirmed the role of $\beta$-ARs in the modulation of angiogenesis and demonstrated that non-selective $\beta$-AR antagonists, but not $\beta 1$-AR selective antagonists, promote apoptosis of cancer cells [40-42]. Propranolol exerts potent anti-tumoral effects, attenuating migration, reducing vascular endothelial growth factor (VEGF) secretion and inducing apoptosis in both cutaneous and uveal melanoma in a dose-dependent manner [43]. Anti-angiogenic effect of propranolol has also been well described in infantile hemangiomas (IHs) and retinopathy of prematurity [39]. In fact, a significant reduction of serum VEGF levels has been demonstrated in infants affected by IHs after one or two months of propranolol treatment [44,45]. A similar effect has been demonstrated in hypoxic retina [46]. Accordingly, VEGF expression is down-regulated by propranolol in a dose-dependent manner in hemangioma-derived endothelial cells [47] and in hemangioma-derived stem cells [48]. All these data suggest that the anti-tumor activity of propranolol relies in part on its ability to block tumor angiogenesis. Besides its anti-angiogenic activity, propranolol affects activities of other cells in tumor microenvironment. In ovarian carcinoma, propranolol decreases macrophage recruitment by tumor mass [49], and in a model of breast cancer it prevents macrophage M2 polarization [50]. In melanoma, propranolol decreases the infiltration of immunosuppressive myeloid cells, such as neutrophils, in the tumor microenvironment and favors the cytotoxic tumor-infiltrating lymphocytes' activity [51]. Moreover, the pathogenic role of stress in promoting melanoma growth in human cells and in mice was described by the efficacy of propranolol used alone $[30,42,52]$ or associated with other drugs [53]. 
Of particular interest is the recent demonstration of the existing relationship between stress and immune depression, which is indicated as a decisive factor for tumor progression and metastasis development [54-56]. The $\beta$-adrenergic system has been identified as one of the major players in the regulation of the immune system. In particular, it was demonstrated that increased catecholamine levels induced both suppression of natural killer (NK) cell cytotoxicity [57-59], leading to tumor metastasis [34,60], and reduction of cytolytic killing ability of antigen-specific CD8 ${ }^{+} \mathrm{T}$ cells [61]. Moreover, $\beta$-adrenergic system promoted an increase of T regulatory (Treg) cell suppressive activity, through $\beta 2$-AR signaling [62] and an accumulation of myeloid-derived suppressor cells (MDSC) in mice [63] and in human patients [64]. These effects were mediated by an increased production of norepinephrine [65]. Interestingly, a preclinical study demonstrated that in mice bearing B16-F10 melanoma cells, treatment with propranolol was able to potentiate immune-based therapies [66]. These preclinical evidences suggested to better explore the possible efficacy of $\beta$-blockers as anti-cancer adjunctive treatment [51,67] and to improve the efficacy of cancer immunotherapy [68].

The strongest evidence of the role played by $\beta$-ARs in regulating distinct aspects of melanoma cancer comes from clinical investigations showing the efficacy of non-selective $\beta$-ARs' antagonists in reducing the malignancy progression. Numerous observational studies suggested that patients treated initially with $\beta$-ARs blockers for cardiovascular diseases and hypertension have also shown reduced melanoma risk [69-71]. De Giorgi et al. demonstrated that patients with thick malignant melanoma (thickness $>1 \mathrm{~mm}$ ) and concomitantly treated with $\beta$-blockers for one year or more, were associated with a reduced risk of tumor progression. In fact, the risk of disease progression (assessed by the presence of sentinel lymph node metastases and lymphatic, in-transit, or visceral metastases) was significantly reduced by $36 \%$ for each year of $\beta$-blockers use. Although the number of patients included in this study was relatively small a significant reduction in mortality was observed in patients treated with $\beta$-blockers [69]. Clinical follow-up of these patients after eight years from treatment with $\beta$-blockers confirmed the reduced disease progression from $45 \%$ to $30 \%$, and reduced mortality from $35 \%$ to $17 \%$ [70]. The study of Lemeshow et al. supports a similar conclusion: a large population-based cohort study showed that the exposure to $\beta$-blockers for more than 90 days prior to diagnosis induced a lower mortality due to melanoma compared to the no-exposure group [71]. However, two large epidemiologic studies performed in patients who received $\beta$-AR antagonists (the majority assuming $\beta 1$-AR selective blockers) did not confirm these results, even though the risk improved with larger amounts of cumulative daily dose [72,73]. A clinicopathological study evaluated the prognostic significance of $\beta 2$-AR expression on surgically resected cutaneous malignant melanoma. This study revealed that $\beta 2$-AR expression was positively correlated with tumor thickness, ulceration, disease stage, and finally with a poor overall survival [74]. A recent study observed a significant survival benefit for patients treated with immunotherapy and taking unselective $\beta$-blockers compared to either those receiving no $\beta$-blockers or $\beta 1$ selective-blockers [66]. Moreover, a more recent prospective study performed in patients with cutaneous melanoma demonstrated that propranolol treatment reduced the risk of recurrence by $80 \%$ [75].

\section{5. $\beta 3-A R$ and Cancer}

The first report, showing that $\beta 3$-AR influences the risk of cancer, suggested that a polymorphism in codon 64 of the $\beta 3-\mathrm{AR}$ gene, that features replacement of tryptophan by arginine (Trp64Arg), decreased the risk of breast cancer in Japanese women. In particular, individuals who simultaneously carried a glutamic acid polymorphism in $\beta 2$-AR gene (Gln27Glu) together with the Trp64Arg $\beta 3$-AR polymorphism had the most markedly reduced risk of breast cancer, with an odds ratio of 0.37 [76]. In a second study, the same $\beta 3$-AR polymorphism (Trp64Arg) was associated with susceptibility to endometrial cancers in overweight/obese individuals [77]. From these first studies, an involvement of $\beta 3-\mathrm{AR}$ in the biology of cancer was beginning to emerge. However, until few years ago, the poor knowledge regarding the $\beta 3$-AR distribution and pharmacology, and the lack of selective tools suitable for the study of this $\beta$-AR subtype, has made difficult to clarify its contribution in the complex 
landscape of tumor biology. Indeed, the presence of $\beta 3$-AR was first established in physiological tissue, primary in brown adipocytes where it mediates thermogenesis [9], and, for many years, its expression in tumor tissues was completely unknown.

For the first time, in 2008, a significant up-regulation of the $\beta 3-A R$ mRNA was described in a tumor tissue; a study involving 41 patients affected by colorectal cancer suggested a possible involvement of the $\beta 3-A R$ in the pathogenesis of this malignancy [78].

In 2013, in a very interesting study, Magnon et al. [79] investigated the role of adrenergic signals in prostate cancer development. To assess the contribute of the $\beta$-ARs, human prostate PC-3 cancer cell line was injected in the prostate of mice genetically deficient for $\beta 2-, \beta 3-$, or both $\beta 2$ - and $\beta 3$-ARs. The first relevant observation was that tumor growth in the prostate was slightly delayed when mice were lacking $\beta 2$ - or $\beta 3-A R$ singularly, but it was severely compromised in ADRB2-/-ADRB3-/mice. Notably, in the double knockout mice, prostate cancer cell dissemination into the lymph nodes and other distant organs was significantly reduced. These results were also confirmed by using the human prostate LNCaP cell line in the same animal model, suggesting that both $\beta 2$ - and $\beta 3$-ARs, expressed in stromal cells of the tumor microenvironment, are critically involved in tumor development and metastatic dissemination of this malignancy.

Recently, $\beta 3-A R$ mRNA and protein expression have been reported across different tumors including vascular tumors, breast cancers and human leukemia cells [80-82]. Notably, in these diseases, B3-AR mRNA or protein expression were strongly increased compared to the healthy counterpart tissues. Moreover, new evidence on $\beta 3$-AR expression was obtained in many other tumors [83], confirming the hypothesis that this $\beta$-AR subtype could play a pivotal role in the onset and/or progression of numerous malignancies [Table 1]. Accordingly, a $\beta 3-A R$ gene variant has been found implicated in the predisposition to gallbladder cancer, the most common and highly aggressive biliary tract malignancy [84]. In addition to several studies on melanoma, discussed below, we recently demonstrated that $\beta 3-\mathrm{AR}$ is expressed in both murine and human neuroblastoma (NB) cell lines, and in tumor biopsies from NB patients; in this study, pharmacological antagonism of $\beta 3$-AR, in a murine syngeneic model of NB, was able to reduce tumor growth by affecting the neuronal differentiation of NB cancer cells [85].

Table 1. Studies Describing $\beta 3$-AR Involvement in the Development of Different Cancers.

\begin{tabular}{|c|c|c|c|c|c|c|}
\hline $\begin{array}{l}\text { ß3-AR (mRNA, } \\
\text { Protein, Gene) } \\
\text { Evaluation }\end{array}$ & Species & $\begin{array}{l}\text { Experimental } \\
\text { Model }\end{array}$ & Disease & $\begin{array}{l}\text { Biological or Clinical } \\
\text { Observations }\end{array}$ & $\begin{array}{l}\text { Study } \\
\text { Type }\end{array}$ & Reference \\
\hline $\begin{array}{c}\text { Trp64Arg } \\
\text { polymorphism }\end{array}$ & human & $\begin{array}{l}\text { tissue } \\
\text { sample }\end{array}$ & breast cancer & $\begin{array}{l}\text { decreased risk of } \\
\text { breast cancer }\end{array}$ & $\begin{array}{l}\text { Case-control } \\
\text { study }\end{array}$ & $\begin{array}{l}\text { Huang XE et al., } \\
2001[76]\end{array}$ \\
\hline $\begin{array}{c}\text { Trp64Arg } \\
\text { polymorphism }\end{array}$ & human & $\begin{array}{l}\text { tissue } \\
\text { sample }\end{array}$ & $\begin{array}{l}\text { endometrial } \\
\text { cancer }\end{array}$ & $\begin{array}{l}\text { susceptibility to } \\
\text { endometrial cancers }\end{array}$ & $\begin{array}{l}\text { Case-control } \\
\text { study }\end{array}$ & $\begin{array}{l}\text { Babol K et al., } \\
2004 \text { [77] }\end{array}$ \\
\hline mRNA expression & human & $\begin{array}{l}\text { tissue } \\
\text { sample }\end{array}$ & $\begin{array}{l}\text { colorectal } \\
\text { cancer }\end{array}$ & $\begin{array}{l}\text { overexpression } \\
\text { related to neoplastic } \\
\text { transformation }\end{array}$ & $\begin{array}{l}\text { Case series } \\
\text { study }\end{array}$ & $\begin{array}{l}\text { Perrone MG et al., } \\
\quad 2008 \text { [78] }\end{array}$ \\
\hline gene knockout & human & $\begin{array}{c}\text { PC-3 cells } \\
\text { and LNCaP } \\
\text { cells in } \\
\text { xenograft } \\
\text { nude mouse } \\
\text { model }\end{array}$ & $\begin{array}{l}\text { prostate } \\
\text { cancer }\end{array}$ & $\begin{array}{l}\text { genetic deletion of } \\
\text { stromal } \beta 2 / 3-A R s \\
\text { prevents the early } \\
\text { phases of tumor } \\
\text { development and } \\
\text { tumor cell } \\
\text { dissemination }\end{array}$ & $\begin{array}{l}\text { Preclinical } \\
\text { study }\end{array}$ & $\begin{array}{l}\text { Magnon C et al., } \\
2013 \text { [79] }\end{array}$ \\
\hline
\end{tabular}


Table 1. Cont.

\begin{tabular}{|c|c|c|c|c|c|c|}
\hline $\begin{array}{l}\text { B3-AR (mRNA, } \\
\text { Protein, Gene) } \\
\text { Evaluation }\end{array}$ & Species & $\begin{array}{l}\text { Experimental } \\
\text { Model }\end{array}$ & Disease & $\begin{array}{l}\text { Biological or Clinical } \\
\text { Observations }\end{array}$ & $\begin{array}{l}\text { Study } \\
\text { Type }\end{array}$ & Reference \\
\hline protein expression & human & $\begin{array}{l}\text { tissue } \\
\text { sample }\end{array}$ & $\begin{array}{c}\text { infantile } \\
\text { haemangioma }\end{array}$ & $\begin{array}{l}\text { strong expression in } \\
\text { the (early) } \\
\text { proliferative phase }\end{array}$ & $\begin{array}{l}\text { Descriptive } \\
\text { study }\end{array}$ & $\begin{array}{l}\text { Chisholm KM et } \\
\text { al., } 2012 \text { [80] }\end{array}$ \\
\hline protein expression & human & $\begin{array}{l}\text { tissue } \\
\text { sample }\end{array}$ & breast cancer & $\begin{array}{l}\text { overexpression } \\
\text { compared to normal } \\
\text { breast tissue }\end{array}$ & \multicolumn{2}{|c|}{$\begin{array}{l}\text { Retrospective } \\
\text { cross-sectional Montoya A et al., } \\
\quad \text { study }\end{array}$} \\
\hline mRNA expression & human & $\begin{array}{c}\text { Nalm-6 } \\
\text { pre-B ALL } \\
\text { cells in } \\
\text { xenograft } \\
\text { mouse } \\
\text { model }\end{array}$ & $\begin{array}{l}\text { acute } \\
\text { lymphoblastic } \\
\text { leukaemia }\end{array}$ & $\begin{array}{l}\text { increased cell } \\
\text { proliferation }\end{array}$ & $\begin{array}{l}\text { Preclinical } \\
\text { study }\end{array}$ & $\begin{array}{c}\text { Lamkin DM et al., } \\
2012 \text { [82] }\end{array}$ \\
\hline protein expression & human & $\begin{array}{l}\text { tissue } \\
\text { sample }\end{array}$ & $\begin{array}{l}\text { different } \\
\text { types of } \\
\text { solid cancer }\end{array}$ & $\begin{array}{l}\text { overexpression } \\
\text { compared to normal } \\
\text { tissues }\end{array}$ & $\begin{array}{l}\text { Case-control } \\
\text { study }\end{array}$ & $\begin{array}{l}\text { Rains SL et al., } \\
\quad 2017 \text { [83] }\end{array}$ \\
\hline $\begin{array}{c}\text { rs4994 } \\
\text { polymorphism }\end{array}$ & human & $\begin{array}{l}\text { tissue } \\
\text { sample }\end{array}$ & $\begin{array}{l}\text { gallbladder } \\
\text { cancer }\end{array}$ & $\begin{array}{l}\text { increased risk of } \\
\text { gallbladder cancer }\end{array}$ & $\begin{array}{l}\text { Case-control } \\
\text { study }\end{array}$ & $\begin{array}{c}\text { Rai R et al., } 2015 \\
\text { [84] }\end{array}$ \\
\hline $\begin{array}{l}\text { protein expression } \\
\text { and modulation }\end{array}$ & $\begin{array}{l}\text { murine, } \\
\text { human }\end{array}$ & $\begin{array}{c}\text { Neuro2A } \\
\text { murine cells } \\
\text { in syngeneic } \\
\text { mouse } \\
\text { model, } \\
\text { SK-N-BE } \\
\text { and BE(2)C } \\
\text { human cells; } \\
\text { tissue } \\
\text { sample }\end{array}$ & neuroblastoma & $\begin{array}{c}\text { } 33 \text {-AR sustains tumor } \\
\text { growth and } \\
\text { proliferation, } \\
\text { promotes stemness } \\
\text { and blocks } \\
\text { differentiation of NB } \\
\text { cells }\end{array}$ & $\begin{array}{l}\text { Preclinical } \\
\text { study }\end{array}$ & $\begin{array}{l}\text { Bruno G et al., } \\
2020 \text { [85] }\end{array}$ \\
\hline $\begin{array}{l}\text { protein expression } \\
\text { and modulation }\end{array}$ & murine & $\begin{array}{l}\text { B16-F10 } \\
\text { syngeneic } \\
\text { mouse } \\
\text { model }\end{array}$ & melanoma & $\begin{array}{l}\text { } 33 \text {-AR blockade } \\
\text { reduces tumor cell } \\
\text { growth and } \\
\text { proliferation, and } \\
\text { tumor vascularization }\end{array}$ & $\begin{array}{l}\text { Preclinical } \\
\text { study }\end{array}$ & $\begin{array}{c}\text { Dal } \\
\text { Monte M et al., } \\
2013 \text { [86] }\end{array}$ \\
\hline $\begin{array}{c}\text { mRNA and } \\
\text { protein expression; } \\
\text { protein } \\
\text { modulation }\end{array}$ & murine & $\begin{array}{l}\text { B16-F10 } \\
\text { syngeneic } \\
\text { mouse } \\
\text { model }\end{array}$ & melanoma & $\begin{array}{l}\beta 3-\mathrm{AR} \text { promotes and } \\
\text { sustains melanoma } \\
\text { growth in concert } \\
\text { with } \beta 1 / 2-\mathrm{ARs}\end{array}$ & $\begin{array}{l}\text { Preclinical } \\
\text { study }\end{array}$ & $\begin{array}{l}\text { Sereni F et al., } \\
\quad 2015 \text { [87] }\end{array}$ \\
\hline $\begin{array}{l}\text { protein } \\
\text { modulation }\end{array}$ & murine & $\begin{array}{l}\text { B16-F10 cell } \\
\text { model }\end{array}$ & melanoma & $\begin{array}{l}\text { iNOS-produced NOis } \\
\text { a downstream effector } \\
\text { of } \beta 3-A R \text { in } \\
\text { melanoma }\end{array}$ & $\begin{array}{l}\text { Preclinical } \\
\text { study }\end{array}$ & $\begin{array}{l}\text { Dal } \\
\text { Monte M et al., } \\
2014[88]\end{array}$ \\
\hline
\end{tabular}


Table 1. Cont.

\begin{tabular}{|c|c|c|c|c|c|c|}
\hline $\begin{array}{l}\text { } \beta 3 \text {-AR (mRNA, } \\
\text { Protein, Gene) } \\
\text { Evaluation }\end{array}$ & Species & $\begin{array}{l}\text { Experimental } \\
\text { Model }\end{array}$ & Disease & $\begin{array}{c}\text { Biological or Clinical } \\
\text { Observations }\end{array}$ & $\begin{array}{l}\text { Study } \\
\text { Type }\end{array}$ & Reference \\
\hline $\begin{array}{l}\text { protein expression } \\
\text { and modulation }\end{array}$ & human & $\begin{array}{l}\text { A375 cells; } \\
\text { tissue } \\
\text { sample }\end{array}$ & melanoma & $\begin{array}{c}\text { } 33 \text {-AR correlates with } \\
\text { melanoma } \\
\text { aggressiveness; } \\
\text { } 33 \text {-AR is involved in } \\
\text { recruitment of } \\
\text { circulating } \\
\text { pre-stromal cells by } \\
\text { the tumor, and } \\
\text { enhances their } \\
\text { pro-tumorigenic } \\
\text { activity }\end{array}$ & $\begin{array}{l}\text { Preclinical } \\
\text { study }\end{array}$ & $\begin{array}{l}\text { Calvani M et al., } \\
2015 \text { [89] }\end{array}$ \\
\hline $\begin{array}{l}\text { protein expression } \\
\text { and modulation }\end{array}$ & murine & $\begin{array}{l}\text { B16-F10 cell } \\
\text { line; B16-F10 } \\
\text { syngeneic } \\
\text { mouse } \\
\text { model }\end{array}$ & melanoma & $\begin{array}{c}\beta 3-\mathrm{AR} \text { promotes } \\
\text { immune tolerance in } \\
\text { melanoma }\end{array}$ & $\begin{array}{l}\text { Preclinical } \\
\text { study }\end{array}$ & $\begin{array}{l}\text { Calvani M et al., } \\
2019 \text { [90] }\end{array}$ \\
\hline $\begin{array}{l}\text { protein expression } \\
\text { and modulation }\end{array}$ & murine & $\begin{array}{l}\text { B16-F10 } \\
\text { syngeneic } \\
\text { mouse } \\
\text { model }\end{array}$ & melanoma & $\begin{array}{c}\text { } 33 \text {-AR blockade } \\
\text { induces } \\
\text { differentiation of } \\
\text { hematopoietic } \\
\text { progenitors in TME }\end{array}$ & $\begin{array}{l}\text { Preclinical } \\
\text { study }\end{array}$ & $\begin{array}{l}\text { Calvani M et } \\
\text { al.,2020 [91] }\end{array}$ \\
\hline $\begin{array}{l}\text { protein expression } \\
\text { and modulation }\end{array}$ & human & A375 cells & melanoma & $\begin{array}{c}\text { } 33 \text {-AR sustains } \\
\text { metabolic and } \\
\text { energetic processes in } \\
\text { cancer cells (Warburg } \\
\text { effect) }\end{array}$ & $\begin{array}{l}\text { Preclinical } \\
\text { study }\end{array}$ & $\begin{array}{l}\text { Calvani M et al., } \\
2018 \text { [92] }\end{array}$ \\
\hline
\end{tabular}

$\mathrm{AR}=$ adrenergic receptor $; \mathrm{iNOS}=$ inducible $\mathrm{NO}$ synthase $; \mathrm{NB}=$ neuroblastoma; $\mathrm{NO}=$ nitric oxide; $\mathrm{TME}=$ tumor microenvironment.

\section{6. $\beta 3-A R$ in Melanoma: Preclinical Studies}

A prospective cohort study has demonstrated that the most used $\beta$-ARs antagonist, propranolol, an approved drug with a non-oncology primary purpose, protected patients with thick cutaneous melanoma from melanoma recurrence [75]. Propranolol is reported to have an order of affinity for $\beta 2-, \beta 1-$ and $\beta 3$-AR respectively of $0.8,1.8$, and $186 \mathrm{nM}[93,94]$. The protective effects observed in melanoma patients treated with propranolol suggested, therefore, a clear involvement of the $\beta 2$-AR subtype in melanoma progression. However, it should be emphasized that an involvement of the other $\beta$-AR subtypes in the observed effects related to melanoma progression cannot be excluded, owing to the broad dosage spectrum with which propranolol and other $\beta$-ARs antagonists have been used in clinical practice [95], and considering that a clear-cut selectivity remains questionable for most $\beta$-blockers [96]. Unfortunately, due to the lack of clinical studies using selective $\beta 3$-AR antagonists in humans, the role of $\beta 3$-AR subtype in melanoma cancer has not been clarified so far at clinical level; nevertheless, its contribution to processes related to melanoma progression is becoming evident, as suggested by pre-clinical evidences.

Studies on murine B16-F10 melanoma cells demonstrated for the first time that the pharmacological $\beta 3-A R$ blockade was able to reduce proliferation and induce apoptosis of melanoma cells in vitro; these effects were also reproduced by using a siRNA molecular approach targeting specific $\beta$-ARs [86]. In the same study, thorough a murine syngeneic experimental model (B16-F10 inoculated in C57BL mice), B3-AR antagonists SR59230A and L-748,377, were both able to significantly reduce melanoma growth in vivo, in comparison with propranolol, by reducing cell proliferation and inducing apoptosis of cancer cells. In addition, the $\beta 3$-AR blockade was also able to reduce tumor vasculature through apoptosis of endothelial cells [87]. The effects of $\beta 3$-AR modulation on melanoma cell proliferation and survival were found mediated by the inducible nitric oxide synthase (iNOS) demonstrating that iNOS-produced nitric oxide (NO) is a downstream effector of $\beta 3$-AR signaling in melanoma [88]. Notably, melanoma 
cell proliferation was inhibited by $\beta 3$-AR blockade either in the presence or not of noradrenaline stimulation, indicating that a partial constitutive $\beta 3$-AR activity, already hypothesized [97], was present in melanoma cells and may contribute to the proliferation process [86].

Both $\beta 2$ - and $\beta 3$-AR were found strongly expressed and actively functional in different stromal cells of the TME, such as cancer-associated fibroblasts (CAF), macrophages and endothelial cells [89]. Indeed, besides the direct effects elicited by the $\beta 3$-AR modulation in melanoma cells, several studies have shown how this receptor is able to regulate stromal, inflammatory, vascular and immune cells of the melanoma microenvironment $[87,89,90]$, thus contributing to the regulation of numerous processes related to melanoma malignancy. In particular, $\beta 3-\mathrm{AR}$ is able to elicit stromal reactivity, sustain secretion of pro-inflammatory cytokines and drive de novo angio/vasculogenesis [89]; the same study has confirmed that $\beta 3$-AR instructs melanoma cells to respond to environmental cell signals and to sense CAFs and macrophages enhancing their tumorigenic and stem-like traits. In regard to the immune regulation, pharmacological and molecular approaches with $\beta$-blockers (propranolol and SR59230A) and specific siRNA targeting of $\beta 2$ - or $\beta 3$-ARs injected in B16-F10 melanoma-bearing mice, suggested an involvement of $\beta 3$-AR subtype in the regulation of the immune-tolerance in melanoma microenvironment [90]. Indeed, $\beta 3$-AR blockade increased the number of NK cells and lymphocytes $\mathrm{CD}^{+}$as well as their cytotoxicity, M1/M2 macrophages ratio and N1 granulocytes, while it abrogated Treg and MDSC sub-populations in tumor mass. By reducing the immune-suppressive and increasing the immune-competent subpopulations of cells in the TME, the $\beta 3$-AR blockade proved the hypothesis that $\beta 3$-ARs might play a role in the promotion of immune tolerance of melanoma. Taken together, these data confirm the pivotal role played by the $\beta 3$-AR in regulating several biological processes related to melanoma progression (Figure 1).

Recently, it has been demonstrated that in murine B16-F10 melanoma-bearing mice, the pharmacological $\beta 3$-AR blockade was able to reduce the expression of cancer stem cell (CSC) markers, and to induce a differentiated phenotype of numerous hematopoietic progenitors recruited in TME [91]. The differentiation of melanoma and various stromal cells involved in pro-tumorigenic processes, brought about by the $\beta 3$-AR blockade at the expense of stemness traits, thus hitting the metastatic potential of melanoma, could represent an efficacious strategy to counteract the progression to advanced stages of this malignancy.

In human A375 melanoma cells, $\beta 3$-AR stimulation through the selective agonist BRL37344 was able to induce a shift from an oxidative to a glycolytic metabolism, sustaining a metabolic process typical of tumor cells and known as Warburg effect [92]. Notably, $\beta 3-A R$ expression was found increased in melanospheres of A375 melanoma cells compared to the parental cell line, once again confirming that the $\beta 3$-AR expression may correlate with pathways related to stemness features of tumor cells. $\beta 3$-AR activation, indeed, induced the expression of specific glycolytic enzymes, such as hexokinase 2 (HKII), monocarboxylate transporter-4 (MCT-4), and glucose transporter-1 (Glut-1), which reflected elevated glucose uptake and lactate overproduction, two key metabolites of the Warburg effect. Moreover, the $\beta 3-\mathrm{AR} / \mathrm{UCP} 2$ axis strongly affected the mitochondrial activity by reducing ATP synthesis and mitochondrial reactive oxygen species (mtROS) content in melanoma cells. All these effects were reverted by using the $\beta 3$-AR antagonist SR59230A, highlighting the crucial role played by the $\beta 3$-AR in regulating molecular signaling that sustain metabolic and energetic processes typical of cancer stem cells [92].

Hypoxic induction of the $\beta 3$-AR protein has been reported in murine B16-F10 and human A375 melanoma cells $[86,89]$. Hypoxia is a well-known condition of solid tumors, including melanoma, able to orchestrate at cellular level a complex program, which leads to pro-tumorigenic events $[98,99]$. The induction of $\beta 3$-AR expression in a hypoxic microenvironment could suggest that tumor cells exploit the activation of $\beta 3$-AR pathways to achieve aggressiveness features required in the tumorigenic process. 


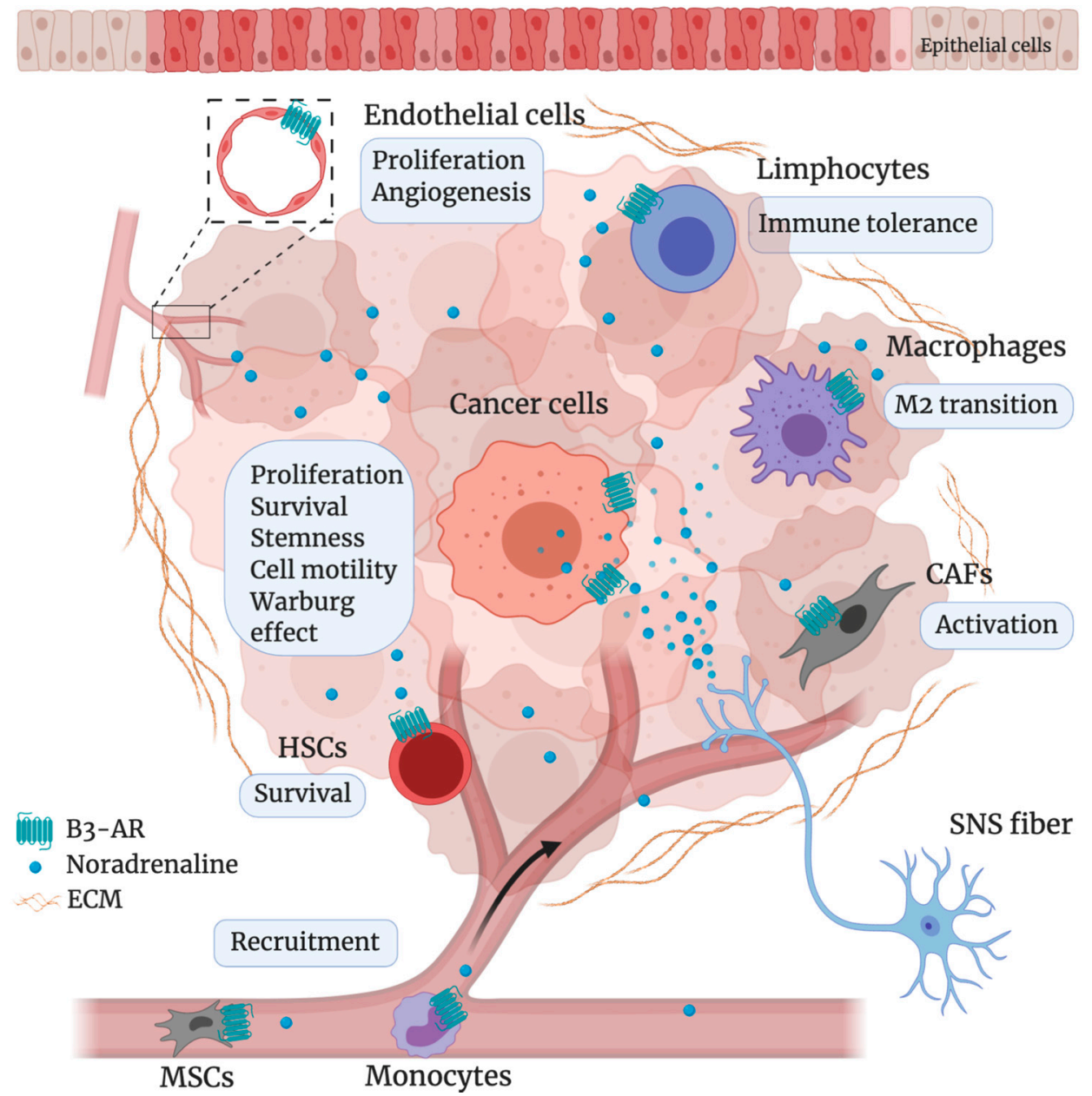

Figure 1. Schematic representation of $\beta 3$-AR-regulated processes in tumor and stromal cells of melanoma microenvironment (TME). A complex network of interaction and crosstalk between tumor and stromal cells of the TME, sustained through $\beta 3$-AR-enanched processes, promotes melanoma progression. $(\mathrm{CAFs}=$ cancer-associated fibroblast; $\mathrm{ECM}=$ extracellular matrix; $\mathrm{HSCs}=$ hematopoietic stem cells; M2 = macrophage type 2; MSCs = mesenchymal stem cells; SNS = sympathetic nervous system). Created with BioRender.

Despite studies investigating the role of $\beta 3-A R$ at clinical level still not being available, the expression of this receptor has been confirmed in melanoma biopsies from different patients. An immuno-histochemical analysis for the expression of $\beta 3$-AR has been assessed in different cutaneous human melanocytic lesions including common and atypical nevi, in situ primary melanoma, superficial spreading melanoma, nodular melanoma, cutaneous, and lymph-nodal metastatic melanoma. Although $\beta 3$-AR was expressed in all examined melanocytic lesions, its expression level, taking into account both staining intensity and percentage of positive cells, was significantly higher in malignant compared to benign lesions [89]. Importantly, in these biopsies $\beta 3$-AR was found expressed also in stromal, endothelial and inflammatory cells of the TME, in accordance with the data obtained at preclinical level. These data clearly suggested that $\beta 3$-AR expression correlates with melanoma malignancy features in human melanocytic lesions.

\section{Conclusions}

Therapeutic options for patients with advanced-stage melanoma have been increased in the last years, and approval of new therapeutic agents such as the checkpoint inhibitors (anti-CTLA4 and anti-PD1 antibodies) and BRAF/MEK inhibitors has opened new expectations for survival. 
Moreover, early clinical data in a small patient population suggests that targeted therapy with BRAF/MEK inhibitors may work in synergy with checkpoint inhibitors and this triplet therapy may improve survival in patients with metastatic melanoma [100]. Despite the therapeutic improvement, some melanomas still remain unresponsive. Therefore, the discovery of new therapeutic strategies, especially for advanced melanoma, is still necessary not only to improve the cure rate but also the quality of life of these patients.

During the years, several studies have accumulated evidence that, in melanoma, both tumor cells and non-tumor stromal cells cooperate in a complex signaling network to sustain tumor growth and progression. This meticulously orchestrated arrangement often underlies the onset of resistance mechanisms or the recurrence of the disease in some therapeutic regimens, especially in those that hit targets involved in a single pathway of the entire network. Accordingly, identifying a therapeutic target involved in regulation of multiple pro-tumor signaling pathways could represent a successful approach.

In light of this, preclinical data summarized in this review have clearly suggested that $\beta 3-A R$ is able to modulate the activity of different cells in the melanoma microenvironment and, consequently, its blockade exerts an important anti-tumor action by affecting multiple pro-tumor signaling pathways. Even though further investigations are needed, especially at clinical level, these first experimental evidences highlight the functional role of the $\beta 3$-AR subtype in melanoma malignancy, and suggest $\beta 3-\mathrm{AR}$ as a therapeutically valid target to counteract melanoma progression.

Author Contributions: Conceptualization, L.F., G.B. and M.C.; writing—original draft preparation, L.F., G.B. and V.D.; writing-review and editing: C.F. and M.C. All authors have read and agreed to the published version of the manuscript.

Funding: Fondazione Meyer provided financial resources.

Conflicts of Interest: The authors declare no conflict of interest.

\section{References}

1. Watson, M.; Holman, D.M.; Maguire-Eisen, M. Ultraviolet Radiation Exposure and Its Impact on Skin Cancer Risk. Semin. Oncol. Nurs. 2016, 32, 241-254. [CrossRef]

2. Carr, S.; Smith, C.; Wernberg, J. Epidemiology and Risk Factors of Melanoma. Surg. Clin. N. Am. 2020, 100, 1-12. [CrossRef] [PubMed]

3. Glazer, A.M.; Winkelmann, R.R.; Farberg, A.S.; Rigel, D.S. Analysis of Trends in US Melanoma Incidence and Mortality. JAMA Dermatol. 2017, 153, 225-226. [CrossRef] [PubMed]

4. Rastrelli, M.; Tropea, S.; Rossi, C.R.; Alaibac, M. Melanoma: Epidemiology, risk factors, pathogenesis, diagnosis and classification. In Vivo 2014, 28, 1005-1011. [PubMed]

5. Gershenwald, J.E.; Guy, G.P., Jr. Stemming the Rising Incidence of Melanoma: Calling Prevention to Action. J. Natl. Cancer Inst. 2015, 108. [CrossRef] [PubMed]

6. Olsen, C.M.; Green, A.C.; Pandeya, N.; Whiteman, D.C. Trends in Melanoma Incidence Rates in Eight Susceptible Populations through 2015. J. Invest. Dermatol. 2019, 139, 1392-1395. [CrossRef] [PubMed]

7. Tang, J.; Li, Z.; Lu, L.; Cho, C.H. $\beta$-Adrenergic system, a backstage manipulator regulating tumour progression and drug target in cancer therapy. Semin. Cancer Biol. 2013, 23, 533-542. [CrossRef]

8. Lands, A.M.; Arnold, A.; Mcauliff, J.P.; Luduena, F.P.; Brown, T.G. Differentiation of receptor systems activated by sympathomimetic amines. Nature 1967, 214, 597-598. [CrossRef]

9. Arch, J.R.; Ainsworth, A.T.; Cawthorne, M.A.; Piercy, V.; Sennitt, M.V.; Thody, V.E.; Wilson, C.; Wilson, S. Atypical beta-adrenoceptor on brown adipocytes as target for anti-obesity drugs. Nature 1984, 309, 163-165. [CrossRef]

10. Bylund, D.B.; Eikenberg, D.C.; Hieble, J.P.; Langer, S.Z.; Lefkowitz, R.J.; Minneman, K.P.; Molinoff, P.B.; Ruffolo, R.R., Jr.; Trendelenburg, U. International Union of Pharmacology nomenclature of adrenoceptors. Pharmacol. Rev. 1994, 46, 121-136.

11. Survival Rates for Melanoma Skin Cancer. 2016. Available online: https://www.cancer.org/cancer/melanomaskin-cancer/detection-diagnosis-staging/survival-rates-for-melanoma-skin-cancer-by-stage.html (accessed on 18 March 2020). 
12. Chapman, P.B.; Einhorn, L.H.; Meyers, M.L.; Saxman, S.; Destro, A.N.; Panageas, K.S.; Begg, C.B.; Agarwala, S.S.; Schuchter, L.M.; Ernstoff, M.S.; et al. Phase III multicenter randomized trial of the Dartmouth regimen versus dacarbazine in patients with metastatic melanoma. J. Clin. Oncol. 1999, 17, 2745-2751. [CrossRef] [PubMed]

13. Middleton, M.R.; Grob, J.J.; Aaronson, N.; Fierlbeck, G.; Tilgen, W.; Seiter, S.; Gore, M.; Aamdal, S.; Cebon, J.; Coates, A.; et al. Randomized phase III study of temozolomide versus dacarbazine in the treatment of patients with advanced metastatic malignant melanoma. J. Clin. Oncol. 2000, 18, 158-166. [CrossRef] [PubMed]

14. Siegel, R.L.; Miller, K.D.; Jemal, A. Cancer statistics, 2020. CA Cancer J. Clin. 2020, 70, 7-30. [CrossRef]

15. Hargadon, K.M.; Johnson, C.E.; Williams, C.J. Immune checkpoint blockade therapy for cancer: An overview of FDA-approved immune checkpoint inhibitors. Int. Immunopharmacol. 2018, 62, 29-39. [CrossRef] [PubMed]

16. Hauschild, A.; Grob, J.J.; Demidov, L.V.; Jouary, T.; Gutzmer, R.; Millward, M.; Rutkowski, P.; Blank, C.U.; Miller, W.H., Jr.; Kaempgen, E.; et al. Dabrafenib in BRAF-mutated metastatic melanoma: A multicentre, open-label, phase 3 randomised controlled trial. Lancet 2012, 380, 358-365. [CrossRef]

17. Hamid, O.; Cowey, C.L.; Offner, M.; Faries, M.; Carvajal, R.D. Efficacy, Safety, and Tolerability of Approved Combination BRAF and MEK Inhibitor Regimens for BRAF-Mutant Melanoma. Cancers 2019, 11, 1642. [CrossRef]

18. Dobry, A.S.; Zogg, C.K.; Hodi, F.S.; Smith, T.R.; Ott, P.A.; Iorgulescu, J.B. Management of metastatic melanoma: Improved survival in a national cohort following the approvals of checkpoint blockade immunotherapies and targeted therapies. Cancer Immunol. Immunother. 2018, 67, 1833-1844. [CrossRef]

19. Larkin, J.; Chiarion-Sileni, V.; Gonzalez, R.; Grob, J.J.; Rutkowski, P.; Lao, C.D.; Cowey, C.L.; Schadendorf, D.; Wagstaff, J.; Dummer, R.; et al. Five-Year Survival with Combined Nivolumab and Ipilimumab in Advanced Melanoma. N. Engl. J. Med. 2019, 381, 1535-1546. [CrossRef]

20. Kandel, M.; Allayous, C.; Dalle, S.; Mortier, L.; Dalac, S.; Dutriaux, C.; Leccia, M.T.; Guillot, B.; Saiag, P.; Lacour, J.P.; et al. Update of survival and cost of metastatic melanoma with new drugs: Estimations from the MelBase cohort. Eur. J. Cancer 2018, 105, 33-40. [CrossRef]

21. Antoni, M.H.; Lutgendorf, S.K.; Cole, S.W.; Dhabhar, F.S.; Sephton, S.E.; McDonald, P.G.; Stefanek, M.; Sood, A.K. The influence of bio-behavioural factors on tumour biology: Pathways and mechanisms. Nat. Rev. Cancer 2006, 6, 240-248. [CrossRef]

22. Cole, S.W.; Sood, A.K. Molecular pathways: Beta-adrenergic signaling in cancer. Clin. Cancer Res. 2012, 18, 1201-1206. [CrossRef] [PubMed]

23. Lutgendorf, S.K.; DeGeest, K.; Dahmoush, L.; Farley, D.; Penedo, F.; Bender, D.; Goodheart, M.; Buekers, T.E.; Mendez, L.; Krueger, G.; et al. Social isolation is associated with elevated tumor norepinephrine in ovarian carcinoma patients. Brain Behav. Immun. 2011, 25, 250-255. [CrossRef] [PubMed]

24. Chakroborty, D.; Sarkar, C.; Basu, B.; Dasgupta, P.S.; Basu, S. Catecholamines regulate tumor angiogenesis. Cancer Res. 2009, 69, 3727-3730. [CrossRef] [PubMed]

25. Entschladen, F.; Drell, T.L., 4th; Lang, K.; Joseph, J.; Zaenker, K.S. Tumour-cell migration, invasion, and metastasis: Navigation by neurotransmitters. Lancet Oncol. 2004, 5, 254-258. [CrossRef]

26. Tas, F.; Karabulut, S.; Guveli, H.; Kurul, S.; Erturk, K.; Guveli, M.; Kinik, H. Assessment of Anxiety and Depression Status in Turkish Cutaneous Melanoma Patients. Asian Pac. J. Cancer Prev. 2017, 18, 369-373. [CrossRef]

27. Sampogna, F.; Paradisi, A.; Iemboli, M.L.; Ricci, F.; Sonego, G.; Abeni, D. Comparison of quality of life between melanoma and non-melanoma skin cancer patients. Eur. J. Dermatol. 2019, 29, 185-191. [CrossRef]

28. Yang, J.; Chen, S.; Li, Y.; Wang, B.; Xin, X.; Xue, X.; Pan, Z.; Lyu, J. Incidence rate and risk factors for suicide death in patients with skin malignant melanoma: A Surveillance, Epidemiology, and End Results analysis. Melanoma Res. 2018. [CrossRef]

29. Dieng, M.; Butow, P.N.; Costa, D.S.; Morton, R.L.; Menzies, S.W.; Mireskandari, S.; Tesson, S.; Mann, G.J.; Cust, A.E.; Kasparian, N.A. Psychoeducational Intervention to Reduce Fear of Cancer Recurrence in People at High Risk of Developing Another Primary Melanoma: Results of a Randomized Controlled Trial. J. Clin. Oncol. 2016, 34, 4405-4414. [CrossRef] [PubMed]

30. Hasegawa, H.; Saiki, I. Psychosocial stress augments tumor development through beta-adrenergic activation in mice. Jpn. J. Cancer Res. 2002, 93, 729-735. [CrossRef] 
31. Goldfarb, Y.; Sorski, L.; Benish, M.; Levi, B.; Melamed, R.; Ben-Eliyahu, S. Improving postoperative immune status and resistance to cancer metastasis: A combined perioperative approach of immunostimulation and prevention of excessive surgical stress responses. Ann. Surg. 2011, 253, 798-810. [CrossRef]

32. Sloan, E.K.; Priceman, S.J.; Cox, B.F.; Yu, S.; Pimentel, M.A.; Tangkanangnukul, V.; Arevalo, J.M.; Morizono, K.; Karanikolas, B.D.; Wu, L.; et al. The sympathetic nervous system induces a metastatic switch in primary breast cancer. Cancer Res. 2010, 70, 7042-7052. [CrossRef] [PubMed]

33. Palm, D.; Lang, K.; Niggemann, B.; Drell, T.L., 4th; Masur, K.; Zaenker, K.S.; Entschladen, F. The norepinephrine-driven metastasis development of PC-3 human prostate cancer cells in BALB/c nude mice is inhibited by beta-blockers. Int. J. Cancer 2006, 118, 2744-2749. [CrossRef] [PubMed]

34. Inbar, S.; Neeman, E.; Avraham, R.; Benish, M.; Rosenne, E.; Ben-Eliyahu, S. Do stress responses promote leukemia progression? An animal study suggesting a role for epinephrine and prostaglandin-E2 through reduced NK activity. PLoS ONE 2011, 6, e19246. [CrossRef] [PubMed]

35. Thaker, P.H.; Han, L.Y.; Kamat, A.A.; Arevalo, J.M.; Takahashi, R.; Lu, C.; Jennings, N.B.; Armaiz-Pena, G.; Bankson, J.A.; Ravoori, M.; et al. Chronic stress promotes tumor growth and angiogenesis in a mouse model of ovarian carcinoma. Nat. Med. 2006, 12, 939-944. [CrossRef]

36. Cole, S.W.; Nagaraja, A.S.; Lutgendorf, S.K.; Green, P.A.; Sood, A.K. Sympathetic nervous system regulation of the tumour microenvironment. Nat. Rev. Cancer 2015, 15, 563-572. [CrossRef]

37. Pérez-Sayáns, M.; Somoza-Martín, J.M.; Barros-Angueira, F.; Diz, P.G.; Gándara Rey, J.M.; García-García, A. Beta-adrenergic receptors in cancer: Therapeutic implications. Oncol. Res. 2010, 19, 45-54. [CrossRef]

38. Colucci, R.; Moretti, S. The role of stress and beta-adrenergic system in melanoma: Current knowledge and possible therapeutic options. J. Cancer Res. Clin. Oncol. 2016, 142, 1021-1029. [CrossRef]

39. Filippi, L.; Dal Monte, M.; Casini, G.; Daniotti, M.; Sereni, F.; Bagnoli, P. Infantile hemangiomas, retinopathy of prematurity and cancer: A common pathogenetic role of the $\beta$-adrenergic system. Med. Res. Rev. 2015, 35, 619-652. [CrossRef]

40. Yang, E.V.; Kim, S.J.; Donovan, E.L.; Chen, M.; Gross, A.C.; Webster Marketon, J.I.; Barsky, S.H.; Glaser, R. Norepinephrine upregulates VEGF, IL-8, and IL-6 expression in human melanoma tumor cell lines: Implications for stress-related enhancement of tumor progression. Brain Behav. Immun. 2009, 23, $267-275$. [CrossRef]

41. Moretti, S.; Massi, D.; Farini, V.; Baroni, G.; Parri, M.; Innocenti, S.; Cecchi, R.; Chiarugi, P. $\beta$-adrenoceptors are upregulated in human melanoma and their activation releases pro-tumorigenic cytokines and metalloproteases in melanoma cell lines. Lab. Invest. 2013, 93, 279-290. [CrossRef]

42. Wrobel, L.J.; Le Gal, F.A. Inhibition of human melanoma growth by a non-cardioselective $\beta$-blocker. J. Invest. Dermatol. 2015, 135, 525-531. [CrossRef] [PubMed]

43. Bustamante, P.; Miyamoto, D.; Goyeneche, A.; de Alba Graue, P.G.; Jin, E.; Tsering, T.; Dias, A.B.; Burnier, M.N.; Burnier, J.V. Beta-blockers exert potent anti-tumor effects in cutaneous and uveal melanoma. Cancer Med. 2019, 8, 7265-7277. [CrossRef] [PubMed]

44. Chen, X.D.; Ma, G.; Huang, J.L.; Chen, H.; Jin, Y.B.; Ye, X.X.; Hu, X.J.; Lin, X.X. Serum-level changes of vascular endothelial growth factor in children with infantile hemangioma after oral propranolol therapy. Pediatr. Dermatol. 2013, 30, 549-553. [CrossRef] [PubMed]

45. Yuan, W.L.; Jin, Z.L.; Wei, J.J.; Liu, Z.Y.; Xue, L.; Wang, X.K. Propranolol given orally for proliferating infantile haemangiomas: Analysis of efficacy and serological changes in vascular endothelial growth factor and endothelial nitric oxide synthase in 35 patients. Br. J. Oral. Maxillofac. Surg. 2013, 51, 656-661. [CrossRef] [PubMed]

46. Ristori, C.; Filippi, L.; Dal Monte, M.; Martini, D.; Cammalleri, M.; Fortunato, P.; la Marca, G.; Fiorini, P.; Bagnoli, P. Role of the adrenergic system in a mouse model of oxygen-induced retinopathy: Antiangiogenic effects of beta-adrenoreceptor blockade. Invest. Ophthalmol. Vis. Sci. 2011, 52, 155-170. [CrossRef] [PubMed]

47. Ji, Y.; Li, K.; Xiao, X.; Zheng, S.; Xu, T.; Chen, S. Effects of propranolol on the proliferation and apoptosis of hemangioma-derived endothelial cells. J. Pediatr. Surg. 2012, 47, 2216-2223. [CrossRef]

48. Zhang, L.; Mai, H.M.; Zheng, J.; Zheng, J.W.; Wang, Y.A.; Qin, Z.P.; Li, K.L. Propranolol inhibits angiogenesis via down-regulating the expression of vascular endothelial growth factor in hemangioma derived stem cell. Int. J. Clin. Exp. Pathol. 2013, 7, 48-55.

49. Armaiz-Pena, G.N.; Gonzalez-Villasana, V.; Nagaraja, A.S.; Rodriguez-Aguayo, C.; Sadaoui, N.C.; Stone, R.L.; Matsuo, K.; Dalton, H.J.; Previs, R.A.; Jennings, N.B.; et al. Adrenergic regulation of monocyte chemotactic 
protein 1 leads to enhanced macrophage recruitment and ovarian carcinoma growth. Oncotarget 2015, 6, 4266-4273. [CrossRef]

50. Qin, J.F.; Jin, F.J.; Li, N.; Guan, H.; Lan, L.; Ni, H.; Wang, Y. Adrenergic receptor $\beta 2$ activation by stress promotes breast cancer progression through macrophages M2 polarization in tumor microenvironment. BMB Rep. 2015, 48, 295-300. [CrossRef]

51. Wrobel, L.J.; Bod, L.; Lengagne, R.; Kato, M.; Prévost-Blondel, A.; Le Gal, F.A. Propranolol induces a favourable shift of anti-tumor immunity in a murine spontaneous model of melanoma. Oncotarget 2016, 7, 77825-77837. [CrossRef]

52. Zhou, C.; Chen, X.; Zeng, W.; Peng, C.; Huang, G.; Li, X.; Ouyang, Z.; Luo, Y.; Xu, X.; Xu, B.; et al. Propranolol induced G0/G1/S phase arrest and apoptosis in melanoma cells via AKT/MAPK pathway. Oncotarget 2016, 7, 68314-68327. [CrossRef] [PubMed]

53. Kuang, X.; Qi, M.; Peng, C.; Zhou, C.; Su, J.; Zeng, W.; Liu, H.; Zhang, J.; Chen, M.; Shen, M.; et al. Propranolol enhanced the anti-tumor effect of sunitinib by inhibiting proliferation and inducing G0/G1/S phase arrest in malignant melanoma. Oncotarget 2017, 9, 802-811. [CrossRef] [PubMed]

54. Shakhar, G.; Ben-Eliyahu, S. In vivo beta-adrenergic stimulation suppresses natural killer activity and compromises resistance to tumor metastasis in rats. J. Immunol. 1998, 160, 3251-3258. [PubMed]

55. Benish, M.; Bartal, I.; Goldfarb, Y.; Levi, B.; Avraham, R.; Raz, A.; Ben-Eliyahu, S. Perioperative use of beta-blockers and COX-2 inhibitors may improve immune competence and reduce the risk of tumor metastasis. Ann. Surg. Oncol. 2008, 15, 2042-2052. [CrossRef] [PubMed]

56. Glasner, A.; Avraham, R.; Rosenne, E.; Benish, M.; Zmora, O.; Shemer, S.; Meiboom, H.; Ben-Eliyahu, S. Improving survival rates in two models of spontaneous postoperative metastasis in mice by combined administration of a beta-adrenergic antagonist and a cyclooxygenase-2 inhibitor. J. Immunol. 2010, 184, 2449-2457. [CrossRef] [PubMed]

57. Ben-Eliyahu, S.; Shakhar, G.; Page, G.G.; Stefanski, V.; Shakhar, K. Suppression of NK cell activity and of resistance to metastasis by stress: A role for adrenal catecholamines and beta-adrenoceptors. Neuroimmunomodulation 2000, 8, 154-164. [CrossRef]

58. Kanemi, O.; Zhang, X.; Sakamoto, Y.; Ebina, M.; Nagatomi, R. Acute stress reduces intraparenchymal lung natural killer cells via beta-adrenergic stimulation. Clin. Exp. Immunol. 2005, 139, 25-34. [CrossRef]

59. Melamed, R.; Rosenne, E.; Shakhar, K.; Schwartz, Y.; Abudarham, N.; Ben-Eliyahu, S. Marginating pulmonary-NK activity and resistance to experimental tumor metastasis: Suppression by surgery and the prophylactic use of a beta-adrenergic antagonist and a prostaglandin synthesis inhibitor. Brain Behav. Immun. 2005, 19, 114-126. [CrossRef]

60. Rosenne, E.; Sorski, L.; Shaashua, L.; Neeman, E.; Matzner, P.; Levi, B.; Ben-Eliyahu, S. In vivo suppression of NK cell cytotoxicity by stress and surgery: Glucocorticoids have a minor role compared to catecholamines and prostaglandins. Brain Behav. Immun. 2014, 37, 207-219. [CrossRef]

61. Nissen, M.D.; Sloan, E.K.; Mattarollo, S.R. $\beta$-Adrenergic Signaling Impairs Antitumor CD8(+) T-cell Responses to B-cell Lymphoma Immunotherapy. Cancer Immunol. Res. 2018, 6, 98-109. [CrossRef]

62. Guereschi, M.G.; Araujo, L.P.; Maricato, J.T.; Takenaka, M.C.; Nascimento, V.M.; Vivanco, B.C.; Reis, V.O.; Keller, A.C.; Brum, P.C.; Basso, A.S. Beta2-adrenergic receptor signaling in CD4+ Foxp3+ regulatory T cells enhances their suppressive function in a PKA-dependent manner. Eur. J. Immunol. 2013, 43, 1001-1012. [CrossRef] [PubMed]

63. Jin, J.; Wang, X.; Wang, Q.; Guo, X.; Cao, J.; Zhang, X.; Zhu, T.; Zhang, D.; Wang, W.; Wang, J.; et al. Chronic psychological stress induces the accumulation of myeloid-derived suppressor cells in mice. PLOS ONE 2013, 8, e74497. [CrossRef] [PubMed]

64. Mundy-Bosse, B.L.; Thornton, L.M.; Yang, H.C.; Andersen, B.L.; Carson, W.E. Psychological stress is associated with altered levels of myeloid-derived suppressor cells in breast cancer patients. Cell Immunol. 2011, 270, 80-87. [CrossRef] [PubMed]

65. Liu, Y.; Wei, J.; Guo, G.; Zhou, J. Norepinephrine-induced myeloid-derived suppressor cells block T-cell responses via generation of reactive oxygen species. Immunopharmacol. Immunotoxicol. 2015, 37, 359-365. [CrossRef]

66. Kokolus, K.M.; Zhang, Y.; Sivik, J.M.; Schmeck, C.; Zhu, J.; Repasky, E.A.; Drabick, J.J.; Schell, T.D. Beta blocker use correlates with better overall survival in metastatic melanoma patients and improves the efficacy of immunotherapies in mice. Oncoimmunology 2017, 7, e1405205. [CrossRef] 
67. Zhou, L.; Li, Y.; Li, X.; Chen, G.; Liang, H.; Wu, Y.; Tong, J.; Ouyang, W. Propranolol Attenuates Surgical Stress-Induced Elevation of the Regulatory T Cell Response in Patients Undergoing Radical Mastectomy. J. Immunol. 2016, 196, 3460-3469. [CrossRef]

68. Wang, W.; Cao, X. Beta-Adrenergic Signaling in Tumor Immunology and Immunotherapy. Crit. Rev. Immunol. 2019, 39, 93-103. [CrossRef]

69. De Giorgi, V.; Grazzini, M.; Gandini, S.; Benemei, S.; Lotti, T.; Marchionni, N.; Geppetti, P. Treatment with $\beta$-blockers and reduced disease progression in patients with thick melanoma. Arch. Intern. Med. 2011, 171, 779-781. [CrossRef]

70. De Giorgi, V.; Grazzini, M.; Benemei, S.; Marchionni, N.; Geppetti, P.; Gandini, S. $\beta$-Blocker use and reduced disease progression in patients with thick melanoma: 8 years of follow-up. Melanoma Res. 2017, 27, 268-270. [CrossRef]

71. Lemeshow, S.; Sørensen, H.T.; Phillips, G.; Yang, E.V.; Antonsen, S.; Riis, A.H.; Lesinski, G.B.; Jackson, R.; Glaser, R. $\beta$-Blockers and survival among Danish patients with malignant melanoma: A population-based cohort study. Cancer Epidemiol. Biomark. Prev. 2011, 20, 2273-2279. [CrossRef]

72. Livingstone, E.; Hollestein, L.M.; van Herk-Sukel, M.P.; van de Poll-Franse, L.; Nijsten, T.; Schadendorf, D.; de Vries, E. $\beta$-Blocker use and all-cause mortality of melanoma patients: Results from a population-based Dutch cohort study. Eur. J. Cancer 2013, 49, 3863-3871. [CrossRef] [PubMed]

73. McCourt, C.; Coleman, H.G.; Murray, L.J.; Cantwell, M.M.; Dolan, O.; Powe, D.G.; Cardwell, C.R. Beta-blocker usage after malignant melanoma diagnosis and survival: A population-based nested case-control study. Br. J. Dermatol. 2014, 170, 930-938. [CrossRef] [PubMed]

74. Shimizu, A.; Kaira, K.; Mori, K.; Kato, M.; Shimizu, K.; Yasuda, M.; Takahashi, A.; Oyama, T.; Asao, T.; Ishikawa, $\mathrm{O}$. Prognostic significance of $\beta 2$-adrenergic receptor expression in malignant melanoma. Tumour Biol. 2016, 37, 5971-5978. [CrossRef] [PubMed]

75. De Giorgi, V.; Grazzini, M.; Benemei, S.; Marchionni, N.; Botteri, E.; Pennacchioli, E.; Geppetti, P.; Gandini, S. Propranolol for Off-label Treatment of Patients With Melanoma: Results From a Cohort Study. JAMA Oncol. 2018, 4, e172908. [CrossRef]

76. Huang, X.E.; Hamajima, N.; Saito, T.; Matsuo, K.; Mizutani, M.; Iwata, H.; Iwase, T.; Miura, S.; Mizuno, T.; Tokudome, S.; et al. Possible association of $\beta 2$ - and $\beta 3$-adrenergic receptor gene polymorphisms with susceptibility to breast cancer. Breast Cancer Res. 2001, 3, 264-269. [CrossRef] [PubMed]

77. Babol, K.; Przybylowska, K.; Lukaszek, M.; Pertynski, T.; Blasiak, J. An association between the Trp64Arg polymorphism in the beta3-adrenergic receptor gene and endometrial cancer and obesity. J. Exp. Clin. Cancer Res. 2004, 23, 669-674. [PubMed]

78. Perrone, M.G.; Notarnicola, M.; Caruso, M.G.; Tutino, V.; Scilimati, A. Upregulation of beta3-adrenergic receptor mRNA in human colon cancer: A preliminary study. Oncology 2008, 75, 224-229. [CrossRef]

79. Magnon, C.; Hall, S.J.; Juan, L.; Xiaonan, X.; Gerber, L.; Freedland, S.J.; Frenette, P.S. Autonomic nerve development contributes to prostate cancer progression. Science 2013, 341, 1236361. [CrossRef]

80. Chisholm, K.M.; Chang, K.W.; Truong, M.T.; Kwok, S.; West, R.B.; Heerema-McKenney, A.E. $\beta$-Adrenergic receptor expression in vascular tumors. Mod. Pathol. 2012, 25, 1446-1451. [CrossRef]

81. Montoya, A.; Amaya, C.N.; Belmont, A.; Diab, N.; Trevino, R.; Villanueva, G.; Rains, S.; Sanchez, L.A.; Badri, N.; Otoukesh, S.; et al. Use of non-selective $\beta$-blockers is associated with decreased tumor proliferative indices in early stage breast cancer. Oncotarget 2017, 8, 6446-6460. [CrossRef]

82. Lamkin, D.M.; Sloan, E.K.; Patel, A.J.; Chiang, B.S.; Pimentel, M.A.; Ma, J.C.; Arevalo, J.M.; Morizono, K.; Cole, S.W. Chronic stress enhances progression of acute lymphoblastic leukemia via $\beta$-adrenergic signaling. Brain Behav. Immun. 2012, 26, 635-641. [CrossRef] [PubMed]

83. Rains, S.L.; Amaya, C.N.; Bryan, B.A. Beta-adrenergic receptors are expressed across diverse cancers. Oncoscience 2017, 4, 95-105. [CrossRef] [PubMed]

84. Rai, R.; Kim, J.J.; Misra, S.; Kumar, A.; Mittal, B. A Multiple Interaction Analysis Reveals ADRB3 as a Potential Candidate for Gallbladder Cancer Predisposition via a Complex Interaction with Other Candidate Gene Variations. Int. J. Mol. Sci. 2015, 16, 28038-28049. [CrossRef] [PubMed]

85. Bruno, G.; Cencetti, F.; Pini, A.; Tondo, A.; Cuzzubbo, D.; Fontani, F.; Strinna, V.; Buccoliero, A.M.; Casazza, G.; Donati, C.; et al. $\beta 3$-adrenoreceptor blockade reduces tumor growth and increases neuronal differentiation in neuroblastoma via SK2/S1P2 modulation. Oncogene 2020, 39, 368-384. [CrossRef] [PubMed] 
86. Dal Monte, M.; Casini, G.; Filippi, L.; Nicchia, G.P.; Svelto, M.; Bagnoli, P. Functional involvement of ß3-adrenergic receptors in melanoma growth and vascularization. J. Mol. Med. 2013, 91, 1407-1419. [CrossRef]

87. Sereni, F.; Dal Monte, M.; Filippi, L.; Bagnoli, P. Role of host $\beta 1$ - and $\beta 2$-adrenergic receptors in a murine model of B16 melanoma: Functional involvement of $\beta 3$-adrenergic receptors. Naunyn Schmiedebergs Arch. Pharmacol. 2015, 388, 1317-1331. [CrossRef]

88. Dal Monte, M.; Fornaciari, I.; Nicchia, G.P.; Svelto, M.; Casini, G.; Bagnoli, P. $\beta 3$-adrenergic receptor activity modulates melanoma cell proliferation and survival through nitric oxide signaling. Naunyn Schmiedebergs Arch. Pharmacol. 2014, 387, 533-543. [CrossRef]

89. Calvani, M.; Pelon, F.; Comito, G.; Taddei, M.L.; Moretti, S.; Innocenti, S.; Nassini, R.; Gerlini, G.; Borgognoni, L.; Bambi, F.; et al. Norepinephrine promotes tumor microenvironment reactivity through ß3-adrenoreceptors during melanoma progression. Oncotarget 2015, 6, 4615-4632. [CrossRef]

90. Calvani, M.; Bruno, G.; Dal Monte, M.; Nassini, R.; Fontani, F.; Casini, A.; Cavallini, L.; Becatti, M.; Bianchini, F.; De Logu, F.; et al. $\beta 3$-Adrenoceptor as a potential immuno-suppressor agent in melanoma. Br. J. Pharmacol. 2019, 176, 2509-2524. [CrossRef]

91. Calvani, M.; Bruno, G.; Dabraio, A.; Subbiani, A.; Bianchini, F.; Fontani, F.; Casazza, G.; Vignoli, M.; De Logu, F.; Frenos, S.; et al. $\beta 3$-Adrenoreceptor Blockade Induces Stem Cells Differentiation in Melanoma Microenvironment. Int. J. Mol. Sci. 2020, 21, 1420. [CrossRef]

92. Calvani, M.; Cavallini, L.; Tondo, A.; Spinelli, V.; Ricci, L.; Pasha, A.; Bruno, G.; Buonvicino, D.; Bigagli, E.; Vignoli, M.; et al. $\beta 3$-Adrenoreceptors Control Mitochondrial Dormancy in Melanoma and Embryonic Stem Cells. Oxid. Med. Cell. Longev. 2018, 2018, 6816508. [CrossRef] [PubMed]

93. Hoffmann, C.; Leitz, M.R.; Oberdorf-Maass, S.; Lohse, M.J.; Klotz, K.N. Comparative pharmacology of human beta-adrenergic receptor subtypes-Characterization of stably transfected receptors in $\mathrm{CHO}$ cells. Naunyn Schmiedebergs Arch. Pharmacol. 2004, 369, 151-159. [CrossRef] [PubMed]

94. Vrydag, W.; Michel, M.C. Tools to study beta3-adrenoceptors. Naunyn Schmiedebergs Arch. Pharmacol. 2007, 374, 385-398. [CrossRef] [PubMed]

95. Dollery, C.T.; Paterson, J.W.; Conolly, M.E. Clinical pharmacology of beta-receptor-blocking drugs. Clin. Pharmacol. Ther. 1969, 10, 765-799. [CrossRef] [PubMed]

96. Baker, J.G. The selectivity of beta-adrenoceptor antagonists at the human beta1, beta2 and beta3 adrenoceptors. Br. J. Pharmacol. 2005, 144, 317-322. [CrossRef]

97. Cai, H.Y.; Xu, Z.J.; Tang, J.; Sun, Y.; Chen, K.X.; Wang, H.Y.; Zhu, W.L. The essential role for aromatic cluster in the $\beta 3$ adrenergic receptor. Acta Pharmacol. Sin. 2012, 33, 1062-1068. [CrossRef]

98. Harris, A.L. Hypoxia-A key regulatory factor in tumour growth. Nat. Rev. Cancer 2002, 2, 38-47. [CrossRef]

99. Bedogni, B.; Powell, M.B. Hypoxia, melanocytes and melanoma-survival and tumor development in the permissive microenvironment of the skin. Pigment. Cell. Melanoma Res. 2009, 22, 166-174. [CrossRef]

100. Broman, K.K.; Dossett, L.A.; Sun, J.; Eroglu, Z.; Zager, J.S. Update on BRAF and MEK inhibition for treatment of melanoma in metastatic, unresectable, and adjuvant settings. Expert Opin. Drug Saf. 2019, 18, 381-392. [CrossRef]

(C) 2020 by the authors. Licensee MDPI, Basel, Switzerland. This article is an open access article distributed under the terms and conditions of the Creative Commons Attribution (CC BY) license (http://creativecommons.org/licenses/by/4.0/). 